\title{
Quality of Breakfast Sausage Containing Legume Flours as Binders
}

\author{
Omojola Andrew Babatunde (Corresponding author) \\ Department of Animal Science, Meat Science Laboratory \\ University of Ibadan, Ibadan, Nigeria \\ Tel: 234-802-342-1935Ｅ-mail: omojolababs@yahoo.com \\ Adetunji, Victor Ayodeji \\ Department of Animal Science, Meat Science Laboratory \\ University of Ibadan, Ibadan, Nigeria \\ Olusola, Olubunmi Olufemi \\ Department of Animal Science, Meat Science Laboratory \\ University of Ibadan, Ibadan, Nigeria
}

Received: May 16, 2013 Accepted: June 1, 2013

doi:10.5296/jbls.v4i2.3701 URL: http://dx.doi.org/10.5296/jbls.v4i2.3701

\begin{abstract}
The effects of different legume flours, viz., soybean, groundnut and cowpea flour, on the quality of breakfast sausage was studied. The study comprised of four treatments, treatment one with sodium caseinate served as the control while the remaining treatments contained soybean, groundnut and cowpea flour at $4 \%$ inclusion level respectively. Each treatment was replicated four times in a completely randomized design. Sausage with sodium caseinate had the highest $(\mathrm{P}<0.05)$ yield $(92.20 \%)$, this was followed by products with cowpea $(89.14 \%)$, soybean $(89.00 \%)$ however, the least was obtained with product containing groundnut $(80.02 \%)$. Sausage samples containing groundnut flour lost an average weight of $28.10 \%$ during cooking $(\mathrm{P}<0.05)$ whilst those containing sodium caseinate, soybean and cowpea flour lost an average weight of 20.91, 21.31 and $21.44 \%$ respectively. The water holding capacity of sodium caseinate products increased significantly compared to that of soybean $(70.75 \%)$ and cowpea flour $(69.34 \%)$ while the least was observed in products containing groundnut flour.
\end{abstract}


Formulations with soybean flour registered higher thiobarbituric acid values (mg malonaldehyde $/ \mathrm{kg}$ sample) of 0.75 as against $0.57,0.52$ and 0.51 for formulations with cowpea flour, sodium caseinate and groundnut flour respectively. Sausage with soybean flour had higher $(\mathrm{P}<0.05)$ overall acceptability $(6.30)$ than products with sodium caseinate $(5.50)$, groundnut (5.10) and cowpea (4.00). However, sausage with cowpea flour had similar ( $\mathrm{P}>0.05)$ moisture content $(79.50 \%)$ with sausage that contained soybean flour $(80.24 \%)$ while the highest $(\mathrm{P}<0.05)$ crude protein content was in treatment with sodium caseinate $(19.50 \%)$ and least in sausage with cowpea flour $(15.55 \%)$. The fat content was highest $(\mathrm{P}<0.05)$ in sausage with cowpea flour $(15.35 \%)$, followed by $13.35 \%$ for sausage with soybean flour, 11.10 for formulation with groundnut flour and $10.25 \%$ for those with sodium caseinate. The quality attributes in terms of nutrient, flavour, juiciness and tenderness were better in sausage with soybean flour compared to sausage produced using other legume flours.

Keywords: Legume flours, Binder, Breakfast sausage, Sausage quality

\section{Introduction}

In the meat processing industry the inclusion of non-meat ingredients are considered an important strategy for reducing overall production costs while maintaining nutritional and sensory qualities of end products (McWatters, 1990). Legumes are of prime importance in human and animal nutrition due to their high protein content (Ustimenko - Bakumovsky, 1983). The use of plant protein products in food as functional ingredients to improve the stability and texture as well as the nutritional quality of the product or for economic reasons is much extended (Messina, 1999). Legume flours are consumed around the world as nutritious protein source, whose consumption has been shown to reduce low density lipoprotein (LDL)-cholesterol and the risk of acquiring type-2 diabetes (Shand et al., 2011).

However, Sodium caseinate used in sausage production as a binder is a stabilized molecule of sodium hydroxide and casein. Reports by Friedman et al., (1984) indicates that stabilizing casein and other molecules by alkalization with sodium hydroxide creates many potentially harmful products since the $\mathrm{pH}$ of protein has been altered, the kidney ends up having difficulty purifying the materials moving through them. This lack of purification has the potential to cause a systemic shut down of the kidney that may cause kidney failure. Casein has also been reported to have the potential to lower overall blood pressure when consumed daily for two weeks (Cadee et al., 2007). Although, casein is a highly nutritious protein, containing many essential amino acids; however, any one with milk allergy must be aware of its presence in any food item. A possible allergic reaction to sodium caseinate is the most likely cause for concern because allergic reactions can vary widely in severity ranging from stomach upset to rashes, to respiratory arrest (Ciacci et al., 2004).

Therefore, research attention has been directed toward increasing utilization of plant protein sources for food use. Such research includes the use of pigeon pea (Akintayo et al., 1999), peanut (McWatters et al., 1976) and sunflower (Hufman et al., 1975). Though, extensive works have been done on utilization of these plant proteins for food, there is insufficient information on the use of soybean, cowpea and groundnut flour as possible replacement for sodium caseinate in sausage production. Therefore, the objective of this study was to compare the yield, 


\section{Ml Macrothink}

Journal of Biology and Life Science ISSN 2157-6076 2013, Vol. 4, No. 2

physico-chemical and eating quality of breakfast sausage prepared using different protein binders.

\section{Materials and Methods}

\subsection{Location of Study}

The research was conducted at the Meat Science Laboratory of the Department of Animal Science, University of Ibadan, Nigeria.

\subsection{Preparation of Legume Flours}

The seeds of the black eye cowpea (Vigna unguiculata) variety were obtained from a local market and soaked in water for ten minutes, while soybean seeds were soaked in hot water $\left(100^{\circ} \mathrm{C}\right)$ for one hour. The testa of the soaked beans were removed and were soaked in hot water $\left(80^{\circ} \mathrm{C}\right)$ for one hour to remove the beany flavour and sundried for 48 hours at an ambient temperature of $28^{\circ} \mathrm{C}$ and ground into flour using a conventional corn mill.

Groundnut seeds (Arachis hypogaea) were obtained from the same market, screened to remove spoilt seeds and impurities. The screened seeds were soaked in warm water $\left(80^{\circ} \mathrm{C}\right)$ over night for easy removal of the testa and dried in an oven (Wagtech Oven, model GP120SE300HYD) for 48 hours at $60^{\circ} \mathrm{C}$ and milled to fine powder using an attrition mill.

\subsection{Sausage Production}

Fresh boneless beef ( $8 \mathrm{~kg}$ ) was obtained from the thigh muscle (Semi membranosus muscle) immediately after slaughter ( within one hour post-mortem), chopped into smaller pieces and minced using a $5 \mathrm{~mm}$ sieve in a tabletop mincer (Breville, Model UTP141, United Kingdom).The minced meat was apportioned into four groups of $2 \mathrm{~kg}$. Group one contained $4 \%$ Sodium caseinate as extender while groups 2, 3, and 4 contained soybeans, cowpea and groundnut flour each at $4 \%$ inclusion level. Each treatment group was replicated four times in a completely randomized design.

Slurry of salt $(\mathrm{NaCl})$, sodium nitrite, phosphate and sugar was prepared in the proportion shown in Table 1.

Table 1. Sausage formulation using different protein extenders (\%)

\begin{tabular}{|l|l|l|l|l|}
\hline Ingredients & Sodium caseinate & Soybean flour & Groundnut flour & Cowpea flour \\
\hline Beef & 65.00 & 65.00 & 65.00 & 65.00 \\
\hline Lard & 20.00 & 20.00 & 20.00 & 20.00 \\
\hline Sodium caseinate & 4.00 & - & - & - \\
\hline Soybean flour & - & 4.00 & - & - \\
\hline Groundnut flour & - & - & 4.00 & \\
\hline Cowpea flour & - & - & - & 4.00 \\
\hline Sugar & 1.00 & 1.00 & 1.00 & 1.00 \\
\hline Sodium nitrite & 0.01 & 0.01 & 0.01 & 0.01 \\
\hline Phosphate & 0.30 & 0.03 & 0.03 & 0.03 \\
\hline Ice water & 3.00 & 3.00 & 3.00 & 3.00 \\
\hline *Dry spice & 2.00 & 2.00 & 2.00 & 2.00 \\
\hline **Green spice & 2.69 & 2.69 & 2.69 & 2.69 \\
\hline Total & 100.00 & 100.00 & 100.00 & 100.00 \\
\hline
\end{tabular}


*Dry spice composition (\%) - Black pepper 15.00: Nutmeg 7.00: Calabash nutmeg 3.00: Red pepper 15.00: Monosodium glutamate 30.00: Thyme 20.00: Curry powder 10.00.

**Green spice composition (\%)- Onion 48.70: Garlic 25.65: Ginger,25.65.

The spices were thoroughly mixed with the meat and the fat. All other ingredients were added in equal amounts $(\mathrm{g} / 100 \mathrm{~g})$ as shown in Table 1 . The minced meat and the other ingredients were mixed thoroughly in a mixer (Oster 8-Speed Blender Model, MG-MB E103TI -Mexico) for 5 minutes. The thoroughly mixed meat samples were stuffed into natural casing (conditioned pig intestine) of about $2 \mathrm{~cm}$ diameter (after stuffing). The stuffed casings were twisted at $10 \mathrm{~cm}$ intervals to obtain shorter linked units.

\subsection{Cooking Loss}

Sausages from the different groups were weighed using an electronic scale (Cuisinart KML-K03BV36246-China) before cooking into an internal temperature of $75^{\circ} \mathrm{C}$ and after cooking.

Cooking loss $=\underline{\text { weight before cooking- weight after cooking } \mathrm{X}} 100$

Weight before cooking

\subsection{Thermal Shortening}

Thermal shortening of the sausages were calculated as the difference in length of each sausage sample before cooking to an internal temperature of $75^{\circ} \mathrm{C}$ in a moist heat cookery and the length after cooking.

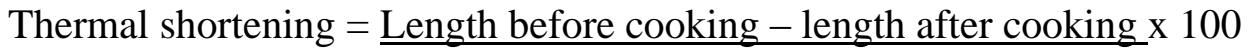

\section{Length before cooking}

\subsection{Drip Loss}

Drip loss was determined by the procedure described by Ibraheem and Abdullahi (2000) and this was calculated using the formula

$$
\text { Drip loss }=\quad \frac{\text { Purge weight } \times 100}{\text { Sample weight }}
$$

\subsection{Water Holding Capacity (WHC)}

Water holding capacity was determined following a slightly modified method of Suzuki et al., (1991). In the process, cooked sausage samples $(10 \times 10 \times 5 \mathrm{~mm})$ from each treatment were weighed individually onto two filter papers and pressed between two plexi glasses for a minute using a vice. The samples were then oven dried at $65^{\circ} \mathrm{C}$ for $48 \mathrm{~h}$ in order to determine the moisture content. The amount of water released from the samples was measure indirectly by measuring the area of the filter paper wetted relative to the area of pressed sample.

The water holding capacity (WHC) of the meat was then calculated as follows (Suzuki et al., 1991) 


$$
\mathrm{WHC}=100-\frac{[(\mathrm{Ar}-\mathrm{Am}) \times 9.47)]}{\mathrm{Wm} \times \mathrm{Mo}} \times 100
$$

Where $\mathrm{Ar}=$ Area of water released form meat $\left(\mathrm{cm}^{2}\right) ; \mathrm{Am}=$ Area of meat sample $\left(\mathrm{cm}^{2}\right) ; \mathrm{Wm}$ $=$ Weight of meat in $\mathrm{mg} ; \mathrm{Mo}=$ Moisture content of meat (\%); 9.47 is a constant factor.

Yield of the product

Yield of the product was calculated using the following formula

Yield $=\frac{\text { Weight of product }}{\text { Initial weight of sample }} \times 100$

\subsection{Sensory Evaluation}

Sensory evaluation was conducted on freshly prepared sausage (day0). A total of twenty panelists (60\% male and $40 \%$ female) with age ranging between 22 and 40 years were selected and trained according to the British Standard Institution (BSI, 1993) guidelines to evaluate the product. The panelist evaluated the products for aroma, texture, taste, juiciness, flavour, tenderness and overall acceptability on a nine- point hedonic scale ( 1 for extremely dislike and 9 extremely like).

The sausages were sliced to approximately $1.5 \mathrm{~cm}$ and wrapped in kitchen foil, blind coded with 3-digit random number and oven warmed at $180^{\circ} \mathrm{C}$ for 5 minutes before serving. The order of serving samples were randomized and counterbalanced so that all treatments occurred equally. The taste evaluation took place under a well illuminated (white fluorescent) laboratory condition (Poste et al., 1991) that ensured independence throughout the entire duration.

\subsection{Proximate Composition}

The products were analyzed for moisture, crude protein, fat and ash content according to the method described by the Association of Official Analytical Chemist (AOAC, 1999). Analyses were conducted in duplicates and all reagents were of analytical grade.

\subsection{Thiobarbituric Acid Reactant Substance (Tbars)}

Samples for TBARS assay were from sausage samples stored at $4^{\circ} \mathrm{C}$ for 5 days. Thiobarbituric acid test was determined through the extraction methods process as described by Rosimini et al. (1996) and Pikul et al. (1998).

\subsection{Statistical Analysis}

All data obtained were subjected to analysis of variance and where significance differences occur, the means were compared using the Duncan's Multiple Range Test (DMRT). The SAS computer soft ware package (1999) was used for all statistical analysis.

\section{Results}

The result of the yield, cooking loss, thermal shortening and water holding capacity of the sausage after cooking are presented in Table 2. Sausage with sodium caseinate had the highest 
$(\mathrm{P}<0.05)$ yield $(92.20 \%)$, this was followed by products with cowpea $(89.14 \%)$ and soybean $(89.00 \%)$ and least value was observed in the product with groundnut flour $(80.02 \%)$. Sausage samples containing groundnut flour lost an average weight of $28.10 \%$ during cooking $(\mathrm{P}<0.05)$ whilst those containing sodium caseinate, soybean and cowpea flour lost average weight of 20.91, 21.31and $21.44 \%$ respectively. Product with sodium caseinate had the highest $(\mathrm{P}<0.05)$ water holding capacity $(84.64 \%)$, followed by sausage containing soybean $(70.75 \%)$ and cowpea flour $(69.34 \%)$ while the least value was obtained in products containing groundnut flour $(61.59 \%)$. The ultimate $\mathrm{pH}$ of the sausage ranged from 6.17 to 6.40 after $24 \mathrm{~h}$ storage at $4^{\circ} \mathrm{C}$.

Table 2. Product yield and physical characteristics of sausage prepared using different binders

\begin{tabular}{|l|l|l|l|l|l|}
\hline $\begin{array}{l}\text { Parameters } \\
(\%)\end{array}$ & Sodium caseinate & $\begin{array}{l}\text { Soybean } \\
\text { flour }\end{array}$ & $\begin{array}{l}\text { Groundnut } \\
\text { flour }\end{array}$ & $\begin{array}{l}\text { Cowpea } \\
\text { flour }\end{array}$ & SEM \\
\hline Yield & $92.20^{\mathrm{a}}$ & $89.00^{\mathrm{b}}$ & $80.02^{\mathrm{c}}$ & $89.14^{\mathrm{b}}$ & 0.07 \\
\hline Thermal shortening & $5.72^{\mathrm{a}}$ & $4.96^{\mathrm{b}}$ & $3.69^{\mathrm{c}}$ & $4.99^{\mathrm{b}}$ & 0.37 \\
\hline Cooking loss & $20.91^{\mathrm{b}}$ & $21.31^{\mathrm{b}}$ & $28.10^{\mathrm{a}}$ & $21.44^{\mathrm{b}}$ & 1.12 \\
\hline Water holding capacity & $84.64^{\mathrm{a}}$ & $70.75^{\mathrm{b}}$ & $61.59^{\mathrm{c}}$ & $69.34^{\mathrm{b}}$ & 2.61 \\
\hline
\end{tabular}

${ }^{\mathrm{abc}}$ Means along the same row with similar superscripts are not significantly different $(\mathrm{P}<0.05)$

The result of the moisture, fat, crude protein and ash content of the sausages are presented in Table 3. The use of sodium caseinate in sausage production increased the crude protein significantly $(\mathrm{P}<0.05)$ whilst the moisture content was lowered. The fat content was highest $(15.35 \%)$ in sausages containing cowpea flour, followed by those with soybean flour, groundnut flour and sodium caseinate with values of $13.35,11.10$ and $10.02 \%$ respectively. Significance differences $(\mathrm{P}<0.05)$ occurred in the ash content of the various sausages. Soybean flour sausage contained the highest ash content (3/40\%) followed by sausage with sodium caseinate $(2.80 \%)$ and $2.60 \%$ for cowpea flour sausage while groundnut flour sausage contained the least $(\mathrm{P}<0.05)$ ash content $(2.10 \%)$.

Table 3. Chemical composition of sausage prepared using different protein binders

\begin{tabular}{|l|l|l|l|l|l|}
\hline Parameters & Sodium Caseinate & $\begin{array}{l}\text { Soybean } \\
\text { flour }\end{array}$ & $\begin{array}{l}\text { Groundnut } \\
\text { flour }\end{array}$ & $\begin{array}{l}\text { Cowpea } \\
\text { flour }\end{array}$ & SEM \\
\hline Moisture $(\%)$ & $70.25^{\mathrm{b}}$ & $80.24^{\mathrm{a}}$ & $69.80^{\mathrm{b}}$ & $79.50^{\mathrm{a}}$ & 1.49 \\
\hline Fat $(\%)$ & $10.25^{\mathrm{d}}$ & $13.35^{\mathrm{b}}$ & $11.10^{\mathrm{c}}$ & $15.35^{\mathrm{a}}$ & 0.06 \\
\hline Crude protein $(\%)$ & $19.50^{\mathrm{a}}$ & $17.60^{\mathrm{b}}$ & $16.80^{\mathrm{c}}$ & $15.55^{\mathrm{d}}$ & 0.56 \\
\hline Ash $(\%)$ & $2.80^{\mathrm{b}}$ & $3.40^{\mathrm{a}}$ & $2.10^{\mathrm{d}}$ & $2.60^{\mathrm{c}}$ & 0.15 \\
\hline TBARS $(\mathrm{mg} / \mathrm{kg})$ & $0.52^{\mathrm{c}}$ & $0.75^{\mathrm{a}}$ & $0.51^{\mathrm{c}}$ & $0.57^{\mathrm{b}}$ & 0.03 \\
\hline
\end{tabular}

${ }^{\mathrm{abc}}$ Means along the same row with similar superscripts are not significantly different $(\mathrm{P}<0.05)$

Thiobarbituric acid reactant substance (TBARS) was determined to measure the lipid peroxidation in the product. The TBARS were between 0.51 and $0.75 \mathrm{mg} / 100 \mathrm{~g}$. The product containing soybean flour had the highest $(\mathrm{P}<0.05)$ value while those with sodium caseinate and groundnut had similar $(\mathrm{P}>0.05)$ values which were the least (Table3).

Sausage with soybean flour had higher overall acceptability score (6.30) than formulations with sodium caseinate (5.50), groundnut (5.10) and cowpea (4.00). Sausage with soybean flour had better score $(\mathrm{P}<0.05)$ in terms of, flavour, juiciness and tenderness compared to sausage 
with other legumes (Table 4).

Table 4. Organoleptic attributes of sausage prepared using different protein extenders

\begin{tabular}{|l|l|l|l|l|l|}
\hline Parameters & Sodium Caseinate & $\begin{array}{l}\text { Soybean } \\
\text { flour }\end{array}$ & $\begin{array}{l}\text { Groundnut } \\
\text { flour }\end{array}$ & $\begin{array}{l}\text { Cowpea } \\
\text { Flour }\end{array}$ & SEM \\
\hline Flavour & $5.70^{\mathrm{b}}$ & $6.31^{\mathrm{a}}$ & $3.66^{\mathrm{c}}$ & $3.90^{\mathrm{c}}$ & 0.35 \\
\hline Juiciness & $6.40^{\mathrm{a}}$ & $6.22^{\mathrm{a}}$ & $5.00^{\mathrm{b}}$ & $5.10^{\mathrm{b}}$ & 0.19 \\
\hline Colour & $6.00^{\mathrm{a}}$ & $5.00^{\mathrm{b}}$ & $5.10^{\mathrm{b}}$ & $5.00^{\mathrm{b}}$ & 0.13 \\
\hline Tenderness & $4.90^{\mathrm{c}}$ & $6.30^{\mathrm{a}}$ & $5.20^{\mathrm{b}}$ & $3.60^{\mathrm{a}}$ & 0.29 \\
\hline Overall Acceptability & $5.50^{\mathrm{b}}$ & $6.30^{\mathrm{a}}$ & $5.10^{\mathrm{c}}$ & $4.00^{\mathrm{d}}$ & 0.21 \\
\hline
\end{tabular}

${ }^{a b c}$ Means along the same row with similar superscripts are not significantly different $(\mathrm{P}<0.05)$

\section{Discussion}

Sausage with sodium caseinate (Control) had the highest yield most probably due to the high WHC of the product and subsequently its low cooking loss. The products with legume protein gave lower yield most probably because mincing destroys the structural integrity of the cell proteins lowering their ability to hold on to its water upon the application of an external force. This became pronounced during cooking since high temperatures cause protein denaturation and a further increase in cooking loss (Lawrie, 1998).

Sausages extended with legume flours had higher moisture content than those with sodium caseinate with the exception of groundnut flour products that had similar $(\mathrm{P}>0.05)$ moisture content value with the control. The findings in the current study contradicted the observation of Prinyawiwatkul et al., (1997) who reported higher moisture contents for nuggets without flour extender. This research utilized unfermented legume flours that possibly had higher potential to absorb and retain moisture in meat formulations as against fermented flours used by Prinyawiwatkul et al., (1997).

The crude protein $(\mathrm{CP})$ of the sausage with different binders varied significantly with the highest in products with sodium caseinate. The $\mathrm{CP}$ of the various binders could be responsible for the differences in the $\mathrm{CP}$ of the products. The cooking loss value most probable had an inverse relationship with the $\mathrm{CP}$ of the products. The high CP content of sausages with soybean flour is indicative of its potential as a possible replacement for sodium caseinate in breakfast sausage formulation. The low fat content of sausages with sodium caseinate and groundnut flour could result in improved shelf storage due to a reduction in the rate of auto-oxidation and rancid flavour development. The high fat content of sausage formulation with cowpea flour could be due to the fact that cowpea flour has a high fat binding property (Philips et al., 2003) and this could be beneficial in meat applications. The high ash and fat content of sausage formulations with soybean and cowpea flour is an indication that these two plant proteins when used in sausage production could be important sources of minerals and energy for consumers (Brown, 1999)

Thiobarbituric Acid Reactant Substances (TBARS) is an indication of the level of lipid peroxidation which eventually predicts the storability of the product. The low TBARS number in the product after storage at $4^{\circ} \mathrm{C}$ for five days could be as a result of the composition of the green spices used in the ingredient formulation (Table 1) that contained some antioxidative 
substances. Minced meat and meat products undergo oxidative changes quickly as grinding exposes lipid membranes to metal oxidation catalyst (Barana et al., 2011). In cured meat, sodium nitrite acts as a very effective antioxidant (Kanner, et al., 1984). The TBARS numbers in each of the product was between the minimum threshold values of $0.5-1 \mathrm{mg}$ malonaldehyde/kg from cooked meat product during storage (Tarladgis, 1960) but was below the level of $1.1 \mathrm{mg} / \mathrm{kg}$ that elicited off flavour in Buffalo meat nugget as reported by Rajendram et al., (2006).

Colour and product appearance are very important criteria that influence consumer patronage (Comfort, 1994) Colour is the single most important factor of meat products that influences consumer buying decisions, as it indicates freshness or otherwise of the product (Boles and Pegg, 2010). The colour rating of the products with legume flours fell within the intermediate range on a nine-point hedonic scale, which is an indication that any of the legumes used in the present study could be used for breakfast sausage preparation without compromising the colour of the product. The sensory score for flavour, tenderness and overall acceptability were highest $(\mathrm{P}<0.05)$ in sausage with soybean flour. This might be attributed to the high moisture content of the product containing soybean flour because high moisture content in a product improves tenderness (Serdaroglu, 2005) and the high flavour perception could be attributed to the inherent flavour of soybean which becomes intense upon cooking.

\section{Conclusion}

Incorporation of $4 \%$ soybean flour as binder in breakfast sausage effectively improved the eating qualities of the product in terms of juiciness, flavour, tenderness and overall acceptability. The yield and water holding capacity of the product were also enhanced however, the TBARS value was highest in products with soybean flour. The results obtained from the study showed that soybean flour have great potential as binder in sausage production and can be successfully used to replace sodium caseinate in breakfast sausage.

\section{References}

Akintayo, E.T., Esusos, K.O. \& Oshodi, A.A. (1999). Emulsifying properties of some legume $\begin{array}{llllll}\text { proteins. Int. J. Food Sci. Technol. } & \text { 33, }\end{array}$ http://dx.doi.org/10.1046/j.1365-2621.1998.00190.x

AOAC International, (1999). In P. Cunniff (Ed.), Official methods of analysis of AOAC International (16th ed.), Gaithersburg, MD, USA: AOAC International.

Barana, C. J., Tomomi, H., Kyu-Ho H, Hiroshi, I. Tomoko, O., Shinichi, S., Michihiro, F., Mitsuo, S. \& Ken-ichiro, S. (2011). Utilization of adzuki bean extract as a natural antioxidant in cured and uncured cooked pork sausages. Meat Science: 89, 150-153. http://dx.doi.org/10.1016/j.meatsci.2011.04.005

Boles, J.A. \& Pegg, R. (2010). Meat Color; Montana State University and Saskatchewan Food Product Innovation, Program University of Saskatchewan.

British Standard Institution (BSI). (1993). Assessors for sensory Analysis: Guide to Selection, Training and Monitoring of Selected Assessors. BS 17667, British Standard Institute, London, 
United Kingdom.

Brown, K. H. (1991). The importance of dietary quality versus quantity for weanlings in the developed countries. A framework for discussion. Food Nutr. Bull. 13(2), 86-93.

Cadee, J. A., Chou-Yue C., Chien-Wei, C., Chien-Ning, H., Su-Lin, C., \& Chin-Kun W. (2007). Bovine Casein Hydrolysate (C12 Peptide) Reduces Blood Pressure in Prehypertensive Subjects. American Journal of Hypertension. 20(1), 1-5. http://dx.doi.org/10.1016/j.amjhyper.2006.06.005

Ciacci, C., Raimondo, C., Paola, I., Francesco, S., Alessandro, P., Daniela,A., Raffaella. T. \& Gabriele M.(2004). Allergy prevalence in adult celiac disease. Journal of Allergy and Clinical Immunology. 113(6), 1199-1203. http://dx.doi.org/10.1016/j.jaci.2004.03.012

Comfort, I. (1994). Colour: Its basis and importance. In: A.M. Pearson and T.R. Dutsin; Quality attributes and their measurements in meat, poultry and fish products. Advances in meat research series. Glasgow Blackie Academic and Professional, pp: 35-77

Friedman, M., Michael R. G. \& Patricia, M. M. (1984). Protein -Alkali Reactions: Chemistry, Toxicology and Nutritional Consequences. Advances in Experimental Medicine and Biology. 177, 367-412. http://dx.doi.org/10.1007/978-1-4684-4790-3_18

Huflman, V. L., Lee, C. K., \& Burns, E. E. (1975). Selected functional properties of sunflower meal (Helianthus annuus). Journal of Food Sci. 40, 70-75. http://dx.doi.org/10.1111/j.1365-2621.1975.tb03738.x

Ibraheem, A. Al-Shedddy \& Abdullahi N. Al-Qwaimer, (2000). Post mortem injection of calcium chloride improves Camel meat tenderness. Resources Bulletin No 98. Resource Center of Agriculture. King Saud University. Pp, 5-16.

Kanner, J., Harel, S., Shagalovich, J., \& Berman, S. (1984). Antioxidant effect of nitrite in

Lawrie, R. A. (1998). Meat Science, (6th ed.). Wood head Publishing Limited, Abington Hall, Abington, Cambridge CBI 6AH, England 223 pages.

McWatters, K. H. (1990). Functional characteristics of cowpea flours in feeds. Journal of American Oil Chemists Society. 67, 272-276. http://dx.doi.org/10.1007/BF02539675

McWatters, K. H., Cherry, J. P. \& Holmes, M. R.(1976). Influence of suspension medium and $\mathrm{pH}$ on functional and protein properties of defatted peanut meal. Journal of Agric Food Chem. 24, 517-519 http://dx.doi.org/10.1021/jf60205a062

Messina, M. J. (1999). Legumes and soybeans overview of their nutritional profiles and health effects. American Journal of Clinical Nutrition. 70, 464S-474S

Phillips RD, McWatters KH, Chinnan MS, Hung YC, Beuchat LR, Sefa-Dedeh S, Sakyi-Dawson E, Ngoddy P, Nnayelugo D, Enwere J, Komey NS, Liu K, Mensa- Wilmot Y, Nnanna IA, Okeke C, Prinyawiwatkul W., \& Saalia F.K. (2003). Utilization of cowpeas for human food. Field Crops Res. 82, 193-213. http://dx.doi.org/10.1016/S0378-4290(03)00038-8 
Pikul J., Leszecynski D. E. \& Kummerow F. A. (1998). Evaluation of three modified TBA methods for measuring lipid oxidation in chicken meat. Journal of Agric. Food Chem. 37, 1309-1313. http://dx.doi.org/10.1021/jf00089a022

Poste, L. M., Mackie, D. A., Butle, G., \& Lamond, E. (1991). Laboratory Methods for Sensory Analysis of Food. Research Branch, Agriculture Canada, Publication1864/E.

Prinyawiwatkul, W., McWatters, K. H., Beuchat, L. R. \& Phillips, R. D. (1997). Optimizing acceptability of chicken nuggets containing fermented cow pea and peanut flours. Journal of Food Science: 62(4), 889-894. http://dx.doi.org/10.1111/j.1365-2621.1997.tb15480.x

Rajendran, T., Anjaneyulu, A. S. R., \& Kondaiah, N. (2006). Quality and shelf life evaluation of emulsion and restructured buffalo meat nuggets at cold storage $\left(4 \pm 1{ }^{\circ} \mathrm{C}\right)$. Meat Science 72 , 373-379. http://dx.doi.org/10.1016/j.meatsci.2005.03.022

Rosimini, M.R., Perlo F., Perez-Alvarez J. A., Pagan-Mareno M. J., Gago-Gago A., Lopez-Santoveoa F. \& Arand-Catalel V. (1996). TBA test by an extractive method applied to 'Pate'. Meat Sci. 42 (1): 103-110. http://dx.doi.org/10.1016/0309-1740(95)00010-0

SAS (999). Statistical analysis system Institutes. User's guide, SAS Institute Inc. Cary N.C.

Serdaroglu M, Yildiz-Turp G \& Abdoimov, K. (2005). Quality of low-fat Meat balls containing legume flours as extenders. Meat Science 70: 99-105. http://dx.doi.org/10.1016/j.meatsci.2004.12.015

Shand, P. J. Hong, G. P. Wang, H., Gerlat, M., Nickerson, M. Wanasundara, \& J. P. D. ( 2011). "Application of legume flours in low-fat meat products formulations for better consumer acceptance," 57 International Congress of Meat Science and Technology, pp. 1-4.

Suzuki A., Kojima N., Ikeuchi Y., Moriyama N., Ishizuka T., \& Tokushige H. (1991) Carcass composition and meat quality of Chinese purebred and European x Chinese cross breeds pig. Meat Science. 29, 31-41. http://dx.doi.org/10.1016/0309-1740(91)90021-H

Tarladgis, B. G., Watts, B. M., Younthan, M. T., \& Dugan, L. R. (1960). A distillation method for the quantitative determination of malonaldehyde in rancid foods. Journal of American Oil Chemists Society 37, 403-406. http://dx.doi.org/10.1007/BF02630824

Ustimenko-Bakumovsky, G. V. (1983). Plant growing in the tropics and sub-tropics. New York: Macmillan Publications

\section{Copyright Disclaimer}

Copyright reserved by the author(s).

This article is an open-access article distributed under the terms and conditions of the Creative Commons Attribution license (http://creativecommons.org/licenses/by/3.0/). 